\title{
PENGARUH ORIENTASI PASAR, KONSUMEN, MEREK, DAN INOVASI LAYANAN TERHADAP KINERJA UMKM DI YOGYAKARTA
}

\section{Gunawan Yulianto dan Ali Hasan}

1,2 Dosen Sekolah Tinggi Pariwisata AMPTA Yogyakarta, Indonesia. Email: ali43ibc@gmail.com

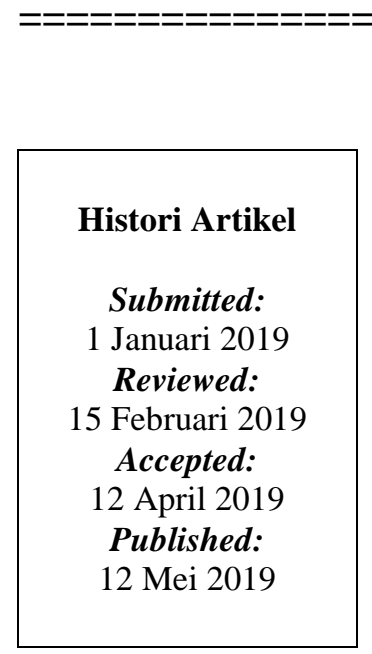

\section{ABSTRACT}

This study seeks to assess the relationship between Micro, Small and Medium Enterprises (MSME) firm performance and market orientation, customer orientation, brand orientation and service innovation in develop for all business. In past, very few studies have focused on the effect of marketing related variables on MSMEs. This study aspires to put some insight on this. Data were collected from creative industry MSME business firm entrepreneurs located in Yogyakarta, A total of 91 MSME entrepreneurs were surveyed in the study through adopting tested survey questionnaires from the past literature. Correlation and regression analysis were used to test the hypotheses. Result indicates that market orientation, customer orientation, brand orientation and service innovation have a positive direct influence on MSME performance.

Keywords: Market Orientation; Customer Orientation; Brand Orientation; Service Innovation; MSME Performance.

\section{PENDAHULUAN}

Penelitian di sektor Usaha Mikro, Kecil dan Menengah (UMKM) akan terus meningkat dari waktu - waktu (Islam et al., 2011). Di negara berkembang, porsi yang lebih besar dari bisnis adalah Usaha Kecil dan Menengah (UMKM). Selama tiga dekade terakhir, UMKM telah menjadi pusat perhatian untuk peneliti sebagai usaha kecil telah memicu pertumbuhan ekonomi suatu negara (Ribeiro-Soriano, 2015). UMKM telah dikenal dengan baik untuk peran kontribusinya dalam menciptakan lapangan kerja baru dan menghasilkan modal keuangan tambahan untuk bisnis (Gilmore, 2011). Signifikansi UMKM dalam mengentaskan kemiskinan melalui penciptaan lapangan kerja di negara berkembang, Chowdhury et al., (2013) mencatat UMKM berkontribusi 40 persen terhadap penciptaan lapangan kerja dalam pembangunan ekonomi sebuah Negara.
Di Indonesia jumlah usaha kecil mencapai 93,4 persen yang tersebar di perkotaan dan pedesaan, usaha menengah 5,1 persen, dan usaha besar 1 persen. Penyerapan tenaga kerja mencapai 97 persen, sementara kontribusi UMKM terhadap PDB mencapai 60,34 persen (BPS, 2018). Sampai saat ini, belum ada penelitian yang menguji secara bersamaan dampak orientasi pasar, pelanggan, merek dan inovasi layanan terhadap kinerja UMKM. Peran UMKM cukup menonjol dalam memberantas kemiskinan, diikuti oleh pertumbuhan ekonomi; dan juga masih sangat sedikit penelitian yang berfokus pada kinerja UMKM (Sarker \& Palit, 2015).

Penerapan konsep dan teori pemasaran di UMKM, tinjauan teoritis yang luas dapat menghasilkan kontribusi teoritis dan implikasi manajerial. Oleh karena itu riset ini fokus pada potensi dan kendala 
pengembangan sektor UMKM dalam mengintegrasikan pasar, pelanggan, merek dan layanan pada kinerja UMKM. UMKM perlu menyeimbangkan strategi kegiatan untuk lingkungan pasar yang cepat berubah, dengan tuntutan untuk memuaskan kebutuhan pelanggan. Mungkin, hampir semua pelaku usaha semakin fokus pada strategi servisasi, berusaha memberikan inovasi layanan yang diharapkan oleh pelanggan (Visnjic et al., 2016). Kolaborasi karyawan dapat mendorong inovasi layanan, pengetahuan eksternal (bersumber dari keluhan pelanggan) memiliki efek positif pada perbaikan layanan

Di sisi lain, kegiatan pemasaran memainkan peran yang kuat dalam memajukan perusahaan agar sukses, di mana orientasi pelanggan tetap menjadi pusat perhatian (Maurya et al., 2015). Kesenjangan studi yang masih langka dalam berkonsentrasi pada pengaruh variabel terkait pemasaran pada kinerja UMKM, mendorong dan memotivasi penulis untuk meneliti secara simultan dampak pasar, pelanggan, merek dan inovasi pada kinerja UMKM. Oleh karena itu, penelitian ini secara khusus dirancang untuk melihat dampak orientasi pasar (OP), orientasi konsumen (OK) orientasi merek $(\mathrm{OM})$ dan inovasi layanan (IL) terhadap kinerja UMKM.

\section{LITERATURE REVIEW}

Gambar 1 memperlihatkan model teoritikal yang menjelaskan sejauhmanakah kinerja UMKM itu dipengaruhi variabel orientasi pasar (OP), orientasi konsumen (OK) orientasi merek $(\mathrm{OM})$ dan inovasi layanan (IL).

Demikian juga usia perusahaan, jumlah karyawan, pengalaman masa lalu (owner) memiliki peran dalam meningkatkan kinerja UMKM

\section{Orientasi Pasar}

Orientasi pasar (OP) dianggap sebagai dasar dari konsep pemasaran dan terkenal karena berkontribusi pada model kinerja bisnis yang berbeda. Konsep OP merupakan faktor penting untuk kesuksesan perusahaan (Ali Hasan, 2018). Temuan empiris terkait OP sebagai budaya organisasi menjadi paling efektif dan efisien dalam menciptakan nilai unggul bagi pembeli, kinerja bisnis terus menerus akan unggul (Asheq and Hossain, 2019).

OP merupakan hasil rekaman intelijen pasar yang berkaitan dengan pelanggan saat ini dan kebutuhan masa depan. Tiga dimensi OP: inisiasi intelijen pasar, penyebaran informasi pasar dan fasilitasi responsifitas di seluruh devisi perusahaan (Ali Hasan, 2018). Hingga saat ini, sejumlah riset pemasaran telah memvalidasi pengaruh $\mathrm{OP}$ positif terhadap kinerja bisnis (Liao et al., 2011). Orientasi pasar secara positif mempengaruhi kinerja pemasaran melalui proses adaptasi produk dan kualitas strategi bisnis (Manek, 2013) arti bahwa OP diperkirakan akan berpengaruh terhadap kinerja UMKM:

$$
\begin{array}{lrr}
H_{1}: & \text { Orientasi Pasar } \\
\text { mempengaruhi kinerja } & \text { UMKM }
\end{array}
$$

$(O P)$

\section{Orientasi Konsumen}

Orientasi konsumen (OK) dapat dijelaskan dari dua perspektif yaitu perspektif individu dan organisasi. Dari sudut pandang individualistik, OK mengacu pada kemampuan tenaga penjualan untuk membantu pelanggan dan menciptakan kualitas hubungan antara pelanggan tenaga penjual. Dari sudut organisasi, OK paling efektif dan efisien dalam membangun perilaku untuk menciptakan nilai unggul bagi pembeli.

OK merupakan keyakinan yang menempatkan minat pelanggan sebagai basis penawaran produk, sementara semua pemangku kepentingan lainnya seperti pemilik, manajer, dan karyawan untuk mengembangkan perusahaan yang menguntungkan jangka panjang. Budaya organisasi yang berorientasi pelanggan lebih relevan bagi UMKM, karena terdiri dari semua pemangku kepentingan yang relevan dan pentingnya OK sebagai pendorong keuntungan jangka panjang perusahaan. 
OK adalah strategi yang menonjol bagi perusahaan kecil sebagai media keunggulan kompetitif yang dapat memisahkan mereka dari perusahaan yang lebih besar (Brockman et al., 2012). UMKM cenderung bisa lebih dekat dengan pelanggan mereka untuk memenuhi tuntutan mereka dan dapat dengan mudah memproses data pelanggan karena kedekatan tersebut (Maurya et al., 2015). Pekovic \& Rolland (2012) menemukan dampak positif dari orientasi pelanggan pada orang-orang penjualan terhadap kinerja perusahaan. Berdasarkan urain ini maka hipotesis yang akan di uji secara empiris adalah :

$\mathrm{H}_{2} \quad$ : Orientasi Pelanggan (OK) mempengaruhi kinerja UMKM

\section{Orientasi Merek}

Urde, Baumgarth, and Merrilees (2013), pertama kali dalam penelitiannya menggunakan istilah orientasi merek - OM dan ia disebut sebagai suatu pendekatan di mana proses organisasi ber putar di sekitar kreasi, pengembangan, dan perlindungan identitas merek dalam interaksi berkelanjutan dengan target pelanggan untuk mencapai keunggulan kompetitif yang langgeng dalam bentuk merek. Definisi ini diikuti dengan kegiatan pengambilan keputusan strategis dan budaya organisasi (Anees-ur-Rehman et al., 2018). OM berupaya untuk memperkuat kinerja bisnis melalui asosiasi interaktif di antara para pemangku kepentingan bisnis yang relevan (Urde, Baumgarth, and Merrilees, 2013).

Perusahaan yang berorientasi merek cenderung memelihara dan meneruskan mereknya kepada orang-orang internal dan pelanggan yang berkaitan dengan upaya meningkatkan kinerja purna jual Zhang et al., (2016) memamerkan hubungan positif antara OM dan kinerja pasar perusahaan karena OM membantu perusahaan mengungguli saingan pasar. Gromark and Melin (2011) menunjukkan hubungan positif antara orientasi merek dan profitabilitas perusahaan; demikian juga Reijonen et al. (2012) membuktikan dampak signifikan orientasi merek terhadap pertumbuhan ekonomi perusahaan. Karena itu hipotesis yang dapat diajukan adalah :

$$
\begin{array}{lrr}
H_{3}: & \text { Orientasi } & \text { Merek } \\
\text { mempengaruhi kinerja } & \text { UMKM. }
\end{array}
$$

(OM)

\section{Inovasi Layanan}

Inovasi layanan (service innovation) (IL) yang dimaknai sebagai sejauh mana UMKM mencapai keunggulan kompetitif berdasarkan inovasi layanan (Storey et al., 2016), itulah sebabnya banyak orang menyebut IL sebagai strategi pengembangan yang dianggap penting bagi keberlanjutan banyak orang dalam mengelola perusahaan (Zhang, et al, 2018). IL terutama mengacu pada perubahan karakteristik layanan. Prosedur inti untuk keberlanjutan perusahaan pengembangan adalah menciptakan nilai dari aset perusahaan dengan mendesain ulang atau meningkatkan produk, layanan, atau metode dengan cara yang inovatif untuk menciptakan dan mempertahankan keunggulan kompetitifnya dengan mengintegrasikan sumber daya perusahaan. Inovasi layanan mendorong perusahaan untuk mengubah perubahan lingkungan menjadi peluang (Hsieh and Chou, 2018)

IL mengacu pada layanan yang berbeda dari yang diketahui konsumen sebelumnya. Organisasi menyediakan layanan yang berbeda dari pengalaman konsumsi sebelumnya (Tseng, et al 2018). IL bukan semata - mata pengembangan layanan baru, tetapi juga kegiatan inovatif yang merevisi dan meningkatkan arus produk, dan sistem pengiriman. Untuk menciptakan pasar baru, perusahaan harus menerapkan layanan yang dapat mengelola pengalaman pelanggan

Inovasi layanan merupakan faktor penentu keberhasilan servisisasi (Lightfoot dan Gebauer, 2011), pencarian driver inovasi layanan seperti kualitas layanan, operasi dan sistem pengiriman diidentifikasi sebagai anteseden dalam membantu pengembangan layanan baru (Storey et al., 2016) . Terkait erat dengan kebutuhan strategis ini adalah pentingnya desain organisasi yang tepat, 
seperti struktur imbalan dan keterlibatan staf front office. (Storey dan Hull, 2010)

Kombinasi kapabilitas internal dan eksternal dapat memfasilitasi pengembangan pengetahuan yang penting bagi proses inovasi layanan (Freiling dan Dressel, 2015). Perusahaan yang berfokus pada layanan berhasil dengan menggunakan pengetahuan eksternal daripada menciptakan pengetahuan internal (Storey et al., 2016), artinya pengetahuan diperoleh dari pelanggan (Carbonell et al., 2009; Melton dan Hartline, 2010) dan hubungan eksternal lainnya untuk meningkatkan inovasi layanan (Storey et al. 2016). Pengetahuan eksternal akan berasimilasi dengan pengetahuan internal, maka indicator-indikator kemampuan internal yang relevan akan meningkatkan inovasi layanan dalam mempengaruhi kinerja bisnis (Storey et al., 2016).

Lin et al. (2009) mentransformasi industri manufaktur menjadi perusahaan yang berorientasi pada layanan. Ia menerapkan gagasan IL dengan memverifikasi hubungan antara inovasi layanan dengan kegiatan manufaktur, mencatat hubungan tatapmuka dengan pelanggan, dan sistem pengiriman. Hasilnya menunjukkan IL memiliki hubungan positif yang signifikan dengan transisi korporasi, mempengaruhi proses redesain prosedur korporasi, desain ulang jaringan perusahaan, dan redefinisi ruang lingkup perusahaan. Ostrom et al. (2010) menemukan bahwa inovasi layanan menciptakan nilai bagi pelanggan, karyawan, pemilik bisnis, mitra aliansi, dan masyarakat melalui penawaran layanan baru, proses layanan, dan layanan model bisnis yang lebih baik. Temuan YuSheng and Ibrahim (2019) menunjukkan bahwa Inovasi layanan memiliki pengaruh langsung pada layanan pengiriman dan kepuasan pelanggan dan loyalitas pelanggan terhadap perusahaan sektor keuangan. Oleh karena itu hipotesis yang akan di uji secara empiris adalah:

$\mathrm{H}_{4}$ : Inovasi layanan (IL) mempengaruhi kinerja UMKM

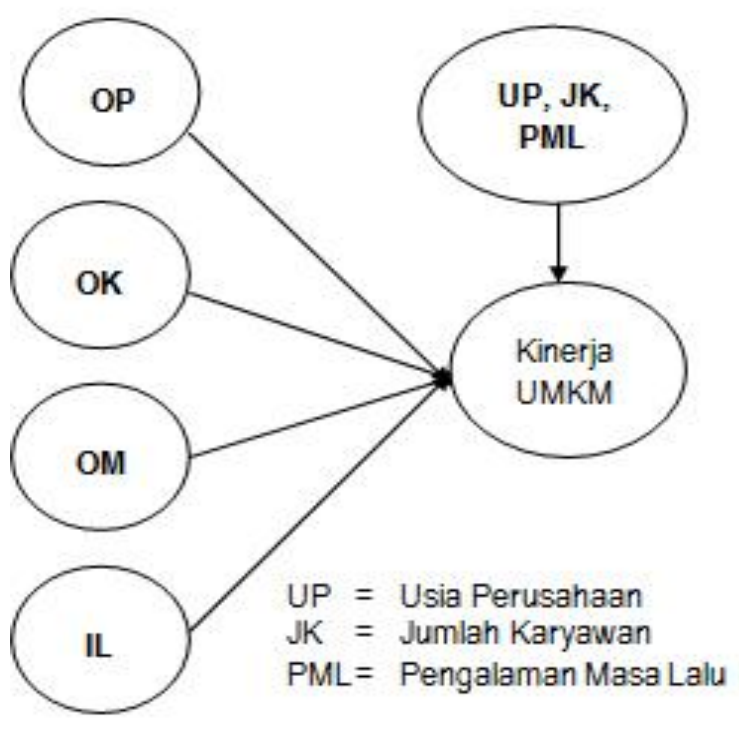

Gambar 1. Model Konseptual Kinerja UMKM

\section{METODE PENELITIAN}

\section{Sampel Penelitian}

Sampel penelitian diperoleh dari himpunan pengusaha kecil menengah di Yogyakarta, ini dipilih karena memiliki klaster usaha yang cukup signifikan. Sampel ditentukan bebrdasarkan purposive probabilitas sampling. Data dikumpulkan dari pelaku bisnis Fashion dan Kuliner. 266 kuesioner terstruktur didistribusikan secara acak kepada para pelaku UMKM, dan hanya 37 pelaku usaha Fashion dan 54 pelaku usaha Kuliner (total 91 responden) yang memberikan respon positif dan lengkap yang kemudian digunakan sebagai unit analisis penelitian ini.

\section{Instrumen Penelitian}

Instrumen penelitian ini menggunakan kuesioner yang terdiri dari dua bagian: pertama variabel control yaitu usia peusahaan, jumlah karyawan dan pengalaman masa lalu pemilik usaha. Bagian kedua item-item yang mengukur OP, OK, OM, IL dan kinerja UMKM dengan skala likert yang dimodifikasi menjadi empat poin 1 - sangat tidak setuju, 2 - tidak setuju, 3 setuju dan 4 sangat setuju

Pengukuran kinerja perusahaan menjadi salah satu bagian penting dalam bisnis, 
penggunaan parameter finansial dan nonfinansial untuk mengukur kinerja UMKM, aspek pertumbuhan dan keuangan perlu dipertimbangkan. Aspek non-finansial juga penting untuk menangkap semua dimensi kinerja perusahaan. Berdasarkan review Laukkanen et al. (2013); Efrat \& Shoham (2013) dan Gurbuz \& Aykol (2009) merekomendasikan bahwa kinerja UMKM diukur dengan empat item, perubahan total pendapatan dan laba penjualan (dalam tiga tahun terakhir), jumlah karyawan dan perubahan basis pelanggan, dengan menggunakan skala Likert yang dimodifikasi menjadi empat point: $\mathbf{1}$ - sangat tidak memuaskan, 2 - tidak memuaskan, 3 memuaskan dan 4 -sangat memuaskan.

OP diukur dengan lima item yang saling terkait yang diadaptasi dari Laukkanen et al. (2013). OK diukur dengan enam item. OM diukur dengan enam item yang dikembangkan oleh Anees-ur-Rehman et al. (2018). Inovasi layanan diukur dengan enam item yang dikembangkan oleh Carbonell et al. (2009) dan untuk menilai keunggulan kompetitif layanan baru. Objektifitas data versi responden sangat berharga bagi UKM (Basco, 2014; Hoffmann et al., 2016) terutama ketika kuesioner mampu menunjukkan ukuran komparatif yang relatif terhadap persaingan bisnis (Helfat, dan Winter., 2011).

\section{Analisis Data}

SPSS 24.0 digunakan untuk menganalisis data, serangkaian program yang digunakan adalah analisis korelasi untuk mengukur korelasi antara variabel dependen (kinerja UMKM) dan variabel independen (OP, OM OK dan IL). Sementara regresi berganda digunakan untuk menguji dampak signifikansi variabel kontrol yaitu usia perusahaan/UMKM, jumlah karyawan dan pengalaman masa lalu pemilik dan variabel independen yaitu OP, OM, OK dan IL terhadap kinerja UMKM.

\section{HASIL DAN PEMBAHASAN}

\section{Hasil Uji Kelayakan Instrumen}

Koefisien Cronbach (1951) digunakan untuk mengukur reliabilitas (konsistensi internal) dari item-item setiap konstruksi variabel. Nilai Cronbach $\geq 0,6$ dianggap sebagai rentang yang dapat diterima untuk mengukur keandalan item. Dalam penelitian ini, Cronbach Alpha (CA) kinerja UMKM (PER), OP, OK dan OM ditemukan masingmasing 0,80, 0,69, 0,66 dan 0,78. Sementara itu untuk mengukur validitas, penelitian ini digunakan exploratory factor analysis dari Kaiser-Meyer-Olkin (KMO), hasilnya = 0,813 yang menunjukkan bahwa data penelitian ini memenuhi principal component analysis-PCA (Kaiser, 1974). Oleh karena itu, PCA dalam rotasi varimax dapat digunakan untuk mengekstraksi faktor total (27) item dari semua variabel untuk menemukan faktor minimum dalam penelitian ini. Tabel 1 menunjukkan bahwa nilai faktor minimum adalah 0,501 dan nilai dapat diterima (Sharma, 1999), dengan demikian, data memenuhi kelayakan validitas.

Table 1 Factor Loading

\begin{tabular}{|c|c|c|c|c|c|}
\hline \multicolumn{6}{|c|}{$\mathbf{K M O}=0.813$} \\
\hline Variabel & Item & $\begin{array}{l}\text { Factor } \\
\text { Loading }\end{array}$ & Variabel & Item & $\begin{array}{l}\text { Factor } \\
\text { Loading }\end{array}$ \\
\hline \multirow{5}{*}{$\begin{array}{l}\text { Kinerja } \\
\text { UMKM } \\
(\mathrm{KNJ}) \\
\mathrm{CA}=0,80\end{array}$} & KNJ1 & 0.769 & \multirow{5}{*}{$\begin{array}{l}\text { Orientasi } \\
\text { Pasar }(\mathrm{OP}) \\
\mathrm{CA}=0,66\end{array}$} & OP1 & 0.530 \\
\hline & KNJ2 & 0.757 & & OP2 & 0.591 \\
\hline & KNJ3 & 0.798 & & OP3 & 0.501 \\
\hline & KNJ4 & 0.831 & & OP4 & 0.662 \\
\hline & & & & OP5 & 0.682 \\
\hline Orientasi & OK1 & 0.521 & Orientasi & OM1 & 0.564 \\
\hline
\end{tabular}




\begin{tabular}{|c|c|c|}
\hline \multirow{5}{*}{$\begin{array}{l}\text { Konsumen } \\
(\mathrm{OK}) \\
\mathrm{CA}=0,69\end{array}$} & OK2 & 0.725 \\
\hline & OK3 & 0.685 \\
\hline & OK4 & 0.553 \\
\hline & OK5 & 0.586 \\
\hline & OK6 & 0.568 \\
\hline \multirow{3}{*}{$\begin{array}{l}\text { Inovasi } \\
\text { Layanan (IL) } \\
\mathrm{CA}=0.81\end{array}$} & IL1 & 0.763 \\
\hline & IL2 & 0.814 \\
\hline & IL3 & 0.791 \\
\hline
\end{tabular}

\begin{tabular}{|l|c|c|}
\hline Merek & OM2 & 0.716 \\
\cline { 2 - 3 }$(\mathrm{OM})$ & OM3 & 0.679 \\
\cline { 2 - 3 } & OM4 & 0.750 \\
\cline { 2 - 3 } & OM5 & 0.792 \\
\cline { 2 - 3 } & OM6 & 0.678 \\
\hline \multirow{5}{*}{} & IL4 & 0.769 \\
\cline { 2 - 3 } & IL5 & 0.757 \\
\cline { 2 - 3 } & IL6 & 0.915 \\
\hline
\end{tabular}

\section{Hasil Uji Kelayakan Variabel}

Empat variabel bebas penelitian ini akan diuji dengan menggunakan model heirarkhi regresi. Agar dapat digunakan, maka variable bebasnya tidak terjadi multikolinieritas, yang diuji dengan Durbin-Watson. Hasil uji Durbin-Watson diperoleh nilai 1,986 yang posisinya berada diantara 1,5 hingga 2,5 , nilai tersebut dapat dibenarkan (Durbin \& Watson, 1950). Semua VIF (Varians Factor Inflasi) berada di bawah nilai ambang 5,00 dan nilai toleransi berada diantara nilai 0,1 hingga 1,$0 ;$ Dengan demikian gejala multicollinearity tidak ditemukan dalam model regresi. Oleh karena itu model heirarkhi regresi dapat digunakan untuk menguji hipotesis penelitian.

\section{Hasil Uji Model Hierarkhi Regresi}

Tabel 2 mempelihatkan bahwa hasil uji model hierarkhi regresi ini menunjukkan paling tidak ada ada delapan temuan penelitian, ini dapat dijelaskan sebagai berikut :

Pertama, semua variable bebas berkorelasi positip dan signifikan dengan kinerja UMKM, OP, $\mathrm{r}=0,190^{*}, \mathrm{OK}, \mathrm{r}=0,382^{* *}$, $\mathrm{OM}, \mathrm{r}=0,452 * *$, dan IL, $\mathrm{r}=0.339 * *$. Angka indeks korelasi menunjukkan besarnya kekuatan dan arah korelasi antara OP, OK, OM dan IL dengan kinerja UMKM. Dari empat variable bebas, tiga variable $\mathrm{OK}$, OM dan IL memperlihatkan korelasi yang kuat $(* *) \mathrm{p}<0.01$, sementara OP berkolesi lemah (*) $\mathrm{p}>0.05$

Kedua, dalam model 1, dan 2 variabel demografis seperti usia perusahaan, jumlah karyawan dan pengalaman masa lalu pemilik bisnis dimasukkan kedalam model regresi hierarkhi berganda dan hanya usia perusahaan yang memperlihatkan koefisien regresi yang signifikan (faktor penentu) dalam meningkatkan kinerja UMKM, $\beta=$ $0,213,0.180 \mathrm{p}<0,01$.

Ketiga, secara keseluruhan dalam model 1 semua variable bebas dan variable demografis berpengaruh signifikan terhadap kinerja UMKM; $\mathrm{F}=3,345 ; \mathrm{p}<0,05$, Kemampuan model 1 menjelaskan varias tambahan kinerja UMKM sebesar 5 persen (R2 Change).

Keempat, demikian juga dalam model 2 semua variable bebas dan usia perusahaan berpengaruh signifikan terhadap kinerja UMKM; F = 23,991; $p<0,001$, Kemapuan model menjelaskan varians tambahan kinerja UMKM sebesar 26,5 persen (R2 Change). Dengan menggunakan variabel kontrol yang signifikan (usia perusahaan), tingkat kontribusi efektif menunjukkan bahwa model 2 jauh lebih besar dari model $1=29.3 \%$ : $3.5 \%$

Kelima, hipotesis 1 diterima $\boldsymbol{\beta}=\mathbf{0 , 1 3 7} \boldsymbol{p}<$ $\mathbf{0 , 0 5}$, ini dapat dijelaskan sebagai berikut : (1) jika variabel bebas yang lain nilainya tetap dan orientasi pada pasar meningkat sebesar satu satuan maka kinerja UMKM akan mengalami kenaikan atau meningkat sebesar 0.137; (2) bahwa orientasi pasar menjadi prediktor yang signifikan terhadap kinerja UMKM. Temuan ini selaras dengan temuan riset sebelumnya (Chew et al., 2008); (3) UMKM yang memiliki tingkat orientasi pasar yang lebih tinggi dapat dengan mudah mengenali, bereaksi dan merespon tuntutan pasar dengan menempatkan barang dan jasa dalam pertukaran yang dapat menghasilkan laba (Zhang et al., 2016); (4) koefisien regresi yang bernilai positif artinya terjadi 
pengaruh sebab akibat antara orientasi pasar dan kinerja UMKM, semakin tinggi orirntasi pasar maka kinerja UMKM semakin meningkat.

Keenam, hipotesis 2 diterima, $\beta=0,240 ; p<$ 0,01. Ini menunjukkan bahwa : (1) jika variabel bebas yang lain nilainya tetap sama (cateris paribus) dan orientasi pada pelanggan meningkat sebesar satu satuan, maka kinerja UMKM akan meningkat sebesar 0.240 ; (2) bahwa orientasi pelanggan berdampak positif terhadap kinerja UMKM. Hasilnya sejalan dengan riset Pekovic \&
Rolland, (2012). (3) hasil ini juga menunjukkan bahwa UMKM yang berorientasi pada pelanggan, sangat mungkin mereka itu dapat meraih kesuksesan, meningkatkan kinerja UMKM secara terus menerus karena setiap fungsi dan karyawan difokuskan untuk memenuhi kebutuhan pelanggan dan trend kebutuhan; (4) koefisien regresi yang bernilai positif artinya terjadi pengaruh sebab akibat antara orientasi pelanggan dan kinerja UMKM, semakin tinggi orientasi pasar, maka kinerja UMKM semakin meningkat.

Tabel 2. Hasil Uji Model Hierarkhi Regresi

\begin{tabular}{|c|c|c|c|c|c|c|c|c|c|c|}
\hline \multirow{2}{*}{$\begin{array}{l}\stackrel{\circlearrowright}{\frac{\delta}{g}} \\
\stackrel{g}{g}\end{array}$} & \multirow{2}{*}{ Variable } & \multicolumn{7}{|c|}{ Model Hierarkhi Regresi } & \multicolumn{2}{|c|}{$\begin{array}{l}\text { Durbin- } \\
\text { Watson }\end{array}$} \\
\hline & & $\mathbf{r}$ & $\begin{array}{l}\text { Adjusted } \\
\qquad \mathbf{R}^{2}\end{array}$ & $\begin{array}{c}\text { R2 } \\
\text { Change }\end{array}$ & $\mathbf{F}$ & $\begin{array}{c}\boldsymbol{\beta} \\
\text { value }\end{array}$ & $\begin{array}{c}\text { t } \\
\text { value }\end{array}$ & Sig. & $\begin{array}{l}\text { Tole } \\
\text { rance }\end{array}$ & VIF \\
\hline \multirow[t]{4}{*}{1} & Fasion & & 0.035 & 0.05 & $3.345^{*}$ & & & & & \\
\hline & Usia UMKM & & & & & 0.213 & 2.989 & 0.003 & 0.989 & 1.011 \\
\hline & Jumlah Karyawan & & & & & 0.036 & 0.512 & 0.609 & 0.997 & 1.003 \\
\hline & $\begin{array}{l}\text { Pengalama masa } \\
\text { lalu }\end{array}$ & & & & & $\begin{array}{c}- \\
0.047\end{array}$ & $\begin{array}{c}- \\
0.666\end{array}$ & 0.506 & 0.987 & 1.013 \\
\hline \multirow[t]{8}{*}{2} & Kuliner & & 0.293 & 0.265 & $23.991 * *$ & & & & & \\
\hline & Usia UMKM & & & & & 0.180 & 2.949 & 0.004 & 0.983 & 1.017 \\
\hline & Jumlah Karyawan & & & & & 0.018 & 0.292 & 0.771 & 0.976 & 1.024 \\
\hline & $\begin{array}{l}\text { Pengalaman masa } \\
\text { lalu }\end{array}$ & & & & & 0.051 & 0.803 & 0.423 & 0.905 & 1.105 \\
\hline & OP & $0.190 *$ & & & & 0.137 & 2.246 & 0.026 & 0.982 & 1.018 \\
\hline & $\mathrm{OK}$ & $0.382 * *$ & & & & 0.240 & 3.570 & 0.000 & 0.817 & 1.224 \\
\hline & $\mathrm{OM}$ & $0.452 * *$ & & & & 0.366 & 5.641 & 0.000 & 0.891 & 1.145 \\
\hline & IL & $0.339 * *$ & & & & 0.197 & 2.325 & 0.029 & 0.991 & 1.021 \\
\hline
\end{tabular}

* signifikansi pada a $0.05(5 \%)$

** signifikansi pada a $0.01(1 \%)$

Ketujuh, hipotesis 3 mensahihkan dirinya bahwa orientasi merek berpengaruh positif dan signifikan terhadap kinerja UMKM, karenanya hipotesis ke 3 ini diterima, $\boldsymbol{\beta}=$ 0,366; $\boldsymbol{p}<0,01$. Ini menyiratkan bahwa : (1) jika varaiabel bebas lain nilainya tetap sama (tdak berubah) dan orientasi serta komitment terhadap merek meningkat sebesar satu satuan, maka kinerja UMKM akan meningkat sebesar 0.366; (2) semakin tinggi orientasi merek sebuah UMKM, Artinya branding yang tepat dapat menghasilkan penjualan yang lebih tinggi, tidak hanya pada suatu produk, tetapi pada produk lain yang terkait. (3) orientasi merek yang kuat mampu mendorong penjualan yang lebih tinggi dan membuatnya tahan terhadap guncangan di pasar, dengan demikian kinerja UMKM akan terus miningkat; (4) koefisien regresi yang bernilai positif artinya terjadi pengaruh sebab akibat antara orientasi merek dan kinerja UMKM, semakin tinggi orientasi merek, maka kinerja UMKM semakin meningkat. 
Kedelapan, hipotesis 4 mempertegas bahwa inovasi layanan sebagai prediktor positif yang secara langsung mempengaruhi kinerja UMKM karena itu hipotesis ke 4 ini diterima, $\beta=0,197 ; \boldsymbol{p}<0,05$. . Ini dapat dipahami bahwa : (1) jika varaiabel bebas lain nilainya tetap sama (cateris paribus) dan inovasi layanan meningkat sebesar satu satuan, maka kinerja UMKM akan meningkat sebesar 0.197 ; (2) riset sebelumnya menunjukkan bahwa inovasi layanan menawarkan cara penting untuk mempertahankan atau mendapatkan keunggulan kompetitif, mengembangkan inovasi layanan UKM lebih sukses. (Storey et al., 2016), Dengan demikian bahwa semakin tinggi kemampuan menciptakan inovasi layanan, maka kinerja UMKM itu akan menjadi lebih tinggi; (3) koefisien regresi yang bernilai positif artinya terjadi pengaruh sebab akibat antara orientasi merek dan kinerja UMKM, semakin tinggi orientasi merek, maka kinerja UMKM semakin meningkat.

\section{PEMBAHASAN}

Secara keseluruhan temuan ini menambah kajian empiris tentang integrasi pengaruh OP, OK, OM dan IL terhadap kinerja UMKM. Selainn itu penelitian ini mendukung temuan penelitian sebelumnya bahwa adopsi OP, OK, OM dan IL dapat meningkatkan kinerja UMKM. Studi ini lebih lanjut menawarkan dukungan teoretis untuk adopsi OP, OK, OM dan IL dalam operasional bisnis. Ini berarti bahwa organisasi bisnis secara langsung dan tidak langsung melalui penggunaan platform OP, OK, OM dan IL yang efektif untuk memberikan layanan bisnis yang baik kepada pelanggan untuk meningkatkan kinerja UMKM dan mencapai pertumbuhan bisnis yang berkelanjutan (Bae dan Kim, 2014; Lee et al., 2012; Lin et al., 2015).

\section{Orientasi Pasar}

Dalam perspektif bisnis, orientasi pasar merupakan salah satu fokus kegiatan bisnis. Ali Hasan (2018) menempatkan orientasi pasar : (1) sebagai budaya untuk mempelajari perkembangan pasar sebagai dasar dalam menciptakan superior value bagi pelanggan; (2) kesediaan berbagi informasi dengan seluruh mitra internal bisnis untuk mengadaptasi perubahan selera pasar, (3) menyediakan norma-norma perilaku mengenai pengembangan dan respon terhadap informasi pasar. dan (4) meyakini sebagai upaya mencegah terjadi penurunan penjualan (being product $\rightarrow$ selling oriented leads to decline menjadi being customer $\rightarrow$ market oriented prevents decline"). (5) hasilnya berkaitan dengan kinerja bisnis terutama ketika orientasi pasar memberi pemahaman yang lebih baik tentang lingkungan dan pelanggannya, (6) adanya hubungan positif antara market oriented dan persepsi manajer atau owner mengenai kinerja bisnis secara keseluruhan, kinerja finansial, dan kinerja produk. Oleh karena itu orientasi pasar perlu dibangun menjadi perilaku usaha yang menempatkan pasar sebagai pusat aktivitas bisnis, menjadikannya sebagai organisasi yang menghasilkan perilaku-perilaku yang dibutuhkan untuk menciptakan "superior value" bagi pembeli dan menghasilkan "superior performance" bagi perusahaan dalam lingkungan tidak pernah mau berhenti berubah.

\section{Orientasi Pelanggan}

Orientasi pelanggan berkaitan dengan kajian tentang keinginan dan kebutuhan pelanggan saat ini dan masa mendatang. Pelanggan akan memilih produk yang mereka butuhkan atau bisa juga karena produk itu sedang trend di pasar. Jika kesesuaian kebutuhan atau trend secara terus menerus dapat diprediksi dan direspon oleh pelaku usaha, akan membuat perusahaan mereka mendapat keuntungan lebih, kinerja bisnis mereka akan terus meningkat.

Memantau kepuasan pelanggan atas produk yang mereka konsumsi perlu dilakukan setiap hari, jangan ragu mendekati setiap pelanggan yang akan meninggalkan warung saudara, jika mereka tidak puas minta waktu pelanggan untuk menjelaskan mengapa mereka tidak puas. Lakukan perbaikan dalam mekanisme layanan yang terus mengalir bagi 
pelanggan, cara ini akan memberi dampak loyal atas produk atau perusahaan saudara. Pelaku usaha memahami bahwa kebutuhan pelanggan yang berubah menjadi masalah bagi perusahaan, mengabaikan perubahan kebutuhan pelanggan, mereka akan mencari perusahaan lain dengan produk yang siap menerima perubahan selera pelanggan.

\section{Orientasi Merek}

Sesuai dengan sasaran riset ini yaitu para pelaku usaha kuliner, maka merek yang paling sering muncul dalam penelitian ini adalah local brand, personal brand dan corporate brand dan brand-brand tersebut dalam banyak pandangan pemilik sebagai sebuah visi mendasar bagi perusahaan mereka. Menurut Ali Hasan (2018) bahwa brand menjadi penuntun arah bisnis, setir yang mengendalikan arah usaha itu akan dibawa, merek yang aktif akan mengkomunikasikan identitas bisnisnya, menciptakan kesadaran, loyalitas pelanggan, dan image bisnis yang sedang di kelola.

Merek hidup dunia tanpa batas, menjadi aset bagi sebuah perusahaan, oleh karena itu membangun merek harus disesuaikan dengan kemampuan internal bisnis baik barkaitan dengan strategi, ide pengembangan, atau memperkuat bisnis yang sudah ada. Merek yang sukses adalah merek-merek yang terus melakukan inovasi dan mengembangkan ideide baik yang terkait dengan produk maupun proses layanan yang terus dikembangkan dan karena itu pelanggan akan menggunakan merek yang sama dimasa mendatang (brand loyalty).

\section{Inovasi Layanan}

Inovasi layanan menjadi bagian penting bagi setiap bisnis termasuk UMKM, mitra ekternal layanan dapat membantu peningkatan penjualan dimana pelanggan tidak harus datang ke rumah makan/ warung, tetapi cukup melalui mitra ekternal mereka (Gojek misalnya). Menurut Kowalkowski et al., (2013); dan Van de Vrande et al., (2009) mempertimbangkan inovasi layanan, dapat membantu proses akuisisi pelanggan baru, pengembangan pengetahuan bersama pelanggan dan kemampuan menginternalisasi pengetahuan tersebut menjadi proses bisnis untuk unggul di pasar (Mina et al. 2014).

Implikasi penting bagi manajemen/owner UMKM bahwa inovasi layanan dapat membantu mempertahankan keunggulan kompetitif bahkan ketika produk menjadi semakin komoditas dan strategi terbaik untuk keluar dari jebakan komoditas, sekaligus dapat mengungguli pesaing, strategi ini tidak dapat mentolerir karyawan yang tidak dapat atau tidak bersedia berpartisipasi aktif dalam proses penerapan inovasi layanan (Chesbrough, 2011; Hewitt dan Roper, 2017).

\section{KESIMPULAN}

Riset ini mempertimbangkan variabelvariabel yang diperkirakan dapat memprediksi kinerja UMKM. Proses pemilihannya didasarkan pada hasil riset sebelumnya yang relevan. Skala pengukuran OP, OK OM dan IL menunjukkan tingkat keandalan dan validitas yang dimodifikasi dari temuan penelitian yang relevan dar studi sebelumnya.

Temuan penelitian menunjukkan bahwa OP memiliki dampak yang signifikan secara statistik dan positif terhadap kinerja UMKM. Studi ini juga mengungkapkan bahwa kinerja UMKM didorong oleh kemampuan perusahaan untuk memenuhi kebutuhan pelanggan dan mengejar peluang yang belum dimanfaatkan. Temuan ini melengkapi hasil Gruber-Muecke \& Hofer (2015) di mana OP secara langsung mempengaruhi kinerja bisnis. Ini menunjukkan bahwa orientasi pasar itu sangat penting bagi UMKM untuk meningkatkan kinerja keuangan dan nonkeuangan mereka.

Alasannya mungkin karena pemilik UMKM kuliner dan fashion selalu berusaha mempertahankannya, diperbarui sendiri tentang tren pasar saat ini dalam bisnis kuliner dan fashion, diikuti oleh tukar informasi pasar yang sengaja untuk wawasan luas yang dibangun dari orientasi pasar. Hasil 
penelitian juga menunjukkan bahwa UMKM yang akan lebih berorientasi pasar, semakin tinggi kinerja yang dicapai.

Temuan secara langsung juga berkaitan dengan orientasi pelanggan yang berdampak positif terhadap kinerja UMKM. Neneh (2018) menemukan hubungan positif antara orientasi pelanggan dan kinerja UKM. Oleh karena itu UMKM beroperasi dalam lingkungan bisnis yang kompetitif, orientasi pelanggan menjadi sangat penting, dapat bermanfaat bagi UMKM dalam memanfaatkan kedekatannya dengan pelanggan untuk memberikan nilai bagi pelanggan yang optimal. Orientasi pelanggan dapat mempercepat kinerja UMKM dengan mempertahankan hubungan yang positif dengan pelanggan, dengan berkonsentrasi pada upaya memaksimalkan nilai pelanggan.

Hasil uji statistik juga menunjukkan bahwa orientasi merek berdampak positif dan signifikan terhadap kinerja UMKM kuliner dan fashion. Hasil ini merekomendasikan bahwa manajemen/owner UMKM perlu berupaya untuk secara terus menerus memperkuat dan meningkatkan citra merek usahanya. Temuan lain berkaitan dengan inovasi layanan UMKM. Hasil penelitian ini menunnjukkan bahwa inovasi layanan mempengaruhi kinerja pertumbuhan UMKM. Partner ekternal dalam inovasi layanan memiliki dampak positif terhadap kinerja UMKM,.

\section{Keterbatasan Riset}

Riset ini mencatat ada enam keterbatasan. Pertama, UMKM yang kami hubungi mungkin mereka sebetulnya memiliki data, tetapi tidak berkenan mempublish data tersebut kepada pihak lain (peneliti) sehingga responden jumlah sangat terbatas. Kedua, riset ini mungkin juga tidak cocok untuk UMKM yang mikro karena integrasi variabel OP, OK, OM dan IL memerlukan sumberdaya tambahan untuk bisa dioperasikan, dan ini tidak mudah bagi usaha mikro. Ketiga, berkonsentrasi pada integrasi variabel OP, OK, OM dan IL serta variabel control dengan model analisis klaster untuk memverifikasi hubungan tiga indikator variabel control. Riset ini tidak menemukan urutan efek karena hanya usia perusahaan yang menghasilkan efek signifikan terhadap kinerja UMKM, sementara jumlah karyawan dan pengalaman owner berpengaruh terhadap kinerja UMKM.

Keempat, mencapai optimasi penggunakan OP, OK, OM dan IL membutuhkan perubahan pola pikir di seluruh devisi organisasi. Penelitian ini menunjukkan bahwa UMKM harus memastikan kolaborasi karyawan mereka dalam proses operasi OP, OK, OM dan IL, Investasi dalam OP, OK, OM dan IL dan memotivasi karyawan diperlukan (Kanninen et al., 2017), kendalanya adalah persepsi investasi antara perusahaan bervariasi.

\section{Rekomendasi}

Uji statistik membuktikan bahwa OP, OK, OM dan IL mampu mendorong peningkatan kinerja UMKM, penting bagi manajer/owner UMKM untuk terus memantau tren pasar saat ini. Dari sudut pandang strategis, budaya organisasi perlu dibentuk untuk mengimplementasikan orientasi pasar secara efektif. Mungkin diperlukan perubahan transformasional struktur UMKM Fashion dan Kuliner yang berbeda, keterlibatan karyawan dalam memantau informasi pasar, yang diikuti dengan keterhubungan antar pemangku kepentingan yang berorientasi pasar.

Di sisi lain, temuan penelitian menunjukkan bahwa semakin banyak juga UMKM berorientasi pelanggan, semakin banyak penjualan dan pendapatan yang akan dicapai perusahaan mewujudkan dan memuaskan kebutuhan pelanggan. UMKM perlu mengembangkan alat pemasaran yang dapat menavigasi kebutuhan dan keinginan pelanggan. Tingkat orientasi merek yang diadopsi oleh UMKM harus lebih menekankan pada diferensiasi produk sebagai merek inti. Orientasi merek membantu menciptakan identitas merek yang solid untuk bisnis. 
Orientasi merek secara signifikan mempengaruhi kinerja UMKM dalam penelitian ini; Pemilik UMKM mungkin lebih tertarik untuk berinvestasi dalam kegiatan branding jika mereka menginginkan lebih banyak keuntungan. Kebutuhan komunikasi pemasaran terpadu di UMKM, diikuti oleh identitas merek (nama perusahaan, kemasan). Secara bersamaan OP, OK, OM dan IL sama pentingnya bagi pemilik UMKM dan karyawan untuk menghargai merek UMKM atau produknya, akan memainkan peran penting dalam memfasilitasi merek UMKM. Inovasi layanan dan kemitraan layanan perlu dilakukan dengan cara mengintegrasikan konsep OP, OK, OM dan IL akan memberikan wawasan baru yang menjanjikan untuk kesuksesan masa depan bisnis/UMKM di pasar yang tidak pernah berhenti berubah.

\section{REFERENSI}

Ali Hasan, 2018. Marketing dan KasusKasus Pilihan. Yogyakarta: Center for Academic Publishing Service.

Anees-ur-Rehman, M., Wong, H.Y., Sultan, P., \& Merrilees, B. 2018. How brandoriented strategy affects the financial performance of B2B SMEs. Journal of Business \& Industrial Marketing, 33(3), 303-315.

Asheq, A., and Hossain, U. 2019. SMEs Performance. Academy of Marketing Studies Journal. 23(1), 1-9

Basco, R 2014. Exploring the influence of the family upon firm performance: Does strategic behaviour matter? International Small Business Journal 32(8): 967-995.

Bae, G. and Kim, D.Y. 2014. The effects of offering menu information on perceived waiting time", Journal of Hospitality Marketing \& Management, . 23(7), 746-767.
BPS - Badan Pusat Statistik, 2018. Posisi Usaha Mikro, Kecil, dan Menengah UMKM. Jakarta: BPS

Lee, Y., Chen, A.N. and Ilie, V. 2012, Can online wait be managed? The effect of filler interfaces and presentation modes on perceived waiting time online, $M I S$ Quarterly, 36(2), 365-394.

Lin, Y.T., Xia, K.N. and Bei, L.T. 2015. Customer's perceived value of waiting time for service events, Journal of Consumer Behaviour, 14 (1) 28-40.

Brockman, K.B., Jones, A.M., \& Becherer, C.R. 2012. Customer orientation and performance in small firms: examining the moderating influence of risktaking, innovativeness and opportunity. Journal of Small Business Management, 50(3), 429-446.

Carbonell, P, Rodríguez-Escudero, A, Pujari, D 2009. Customer involvement in new service development: An examination of antecedents and outcomes. Journal of Product Innovation Management 26(5): 536-550. 33(7): 774-793.

Chesbrough, H 2011. The case for open services innovation: The commodity trap. California Management Review 53(3): 5-20.

Chowdhury, M.S.A., Azam, M.K.G., \& Islam, S. 2013. Problems and prospects of SME financing in Bangladesh. Asian Business Review, 2(2), 51-58.

Cronbach, L.J. 1951. Coefficient alpha and the internal structure of tests. Psychometrika, 16(3), 297-334.

Durbin, J., \& Watson, G.S. 1950. Testing for serial correlation in least squares regression I. Biometrika, 37(4), 409428. 
Efrat, K., \& Shoham, A. 2013. The interaction between environment and strategic orientation in born globals' choice of entry mode. International Marketing Review, 30(6), 536-558.

Freiling, J, Dressel, K. 2015. Exploring constrained rates of adoption of total cost of ownership models: A servicedominant logic analysis. International Small Business Journal. 33(7): 774793.

GilOPre, A. 2011. Entrepreneurial and SME marketing. Journal of Research in Marketing and Entrepreneurship, 13(2) 137-145.

Gromark, J., \& Melin, F. 2011. The underlying dimensions of brand orientation and its impact on financial performance. Journal of Brand Management, 18(6), 394-410.

Gruber-Muecke, T., \& Hofer, K.M. 2015. Market orientation, entrepreneurial orientation and performance in emerging markets. International Journal of Emerging Markets, 10(3), 560-571.

Helfat, C, Winter, S. 2011. Untangling dynamic and operational capabilities: Strategy for the $(\mathrm{N})$ ever-changing world. Strategic Management Journal 32(11): 1243-1250.

Hewitt-Dundas, N, Roper, S 2017. Exploring market failures in open innovation. International Small Business Journal 36(1): 23-40.

Hoffmann, C, Wulf, T, Stubner, S 2016. Understanding the performance consequences of family involvement in the top management team: The role of long-term orientation. International Small Business Journal 34(3): 345368.
Hsieh, Y.H.; Chou, Y.H. 2018, modeling the impact of service innovation for small and medium enterprises: A system dynamics approach. Stimulus model Practice and Theory 82, 84-102.

Islam, M.A., Khan, MA., Obaidullah, A.Z.M., \& Alam, S.A. 2011. Effect of entrepreneur and firm characteristics on the business success of SMEs. International Journal of Business and Management, 6(3), 289-299.

Kaiser, H. F. 1974. An index of factorial simplicity. Psychometrika, 39, 3136.

Kanninen, T, Penttinen, E, Tinnilä, M. 2017. Exploring the dynamic capabilities required for servitization:Business Process Management Journal 23(2): 226-247.

Kowalkowski, C, Witell, L, Gustafsson, A. 2013. Any way goes: Identifying value constellations for service infusion in SMEs. Industrial Marketing Management 42(1): 18-30.

Laukkanen, T., Nagy, G., Hirvonen, S., Reijonen, H., \& Pasanen, M. 2013. The effect of strategic orientations on business performance in SMEs. International Marketing Review, 30(6), 510-535.

Liao, S.H., Chang, W.J., Wu, C.C., \& Katrichis, J.M. 2011. A survey of market orientation research (19952008). Industrial Marketing Management, 40(2) 301-310.

Lightfoot, H, Gebauer, H 2011. Exploring the alignment between service strategy and service innovation. Journal of Service Management 22(5): 664-683.

Lin, Y.H.; Wann, J.W.; Lu, T.J. 2009, The study of transforming manufacturing firms into service- 
oriented business: An SME perspective. Journal Technology Management. 14, 59-96.

Manek, Daniel, 2013. Analisis Pengaruh Orientasi Pasar Terhadap Kinerja Pemasaran Pada Perusahaan Pengolahan di Kota Semarang. Jurnal Sains Pemasaran Indonesia. 12(2), 121 - 148

Maurya, U.K., Mishra, P., \& Anand, S., \& Kumar, N. 2015. Corporate identity, customer orientation and performance of SMEs: Exploring the linkages. IIMB Management Review, 27(3), 159-174.

Mina, A, Bascavusoglu-Moreau, E, Hughes, A 2014. Open service innovation and the firm's search for external knowledge. Research Policy 43(5): 853-866.

Neneh, B.N. 2018. Customer orientation and SME performance: the role of networking ties. African Journal of Economic and Management Studies, 9(2), 178-196.

Ostrom, A.L.; Bitner, M.J.; Brown, S.W.; Burkhard, K.A.; Goul, M.; SmithDaniels, V.; Rabinovich, E. 2010. moving forward and making a difference: Research priorities for the science of service. Journal Service Review. 18, 127-159.

Pekovic, S., \& Rolland, S. 2012. An empirical investigation of the effect of customer orientation on the busines $\mathrm{s}$ performance of French firms: A firm-level analysis of direct and moderation effects. Recherche et Applications en Marketing, 27(4), 1137.

Reijonen, H., Laukkanen, T., Komppula, R., \& Tuominen, S. 2012. Are growing SMEs more market and brandoriented? Journal of Small Business Management, 50(4), 699-716.
Ribeiro-Soriano, D. 2017. Small business and entrepreneurship: Their role in economic and social development. Entrepreneurship \& Regional Development, 29(2), 1-3.

Sarker, S., \& Palit, M. 2015. Strategic orientation and performance of SMEs. International Journal of Entrepreneurship and Small Business, 24(4), 572-586.

Sharma, S. 1999. Applied Multivariate Techniques. Jurnal of Operational Research. 114. 1 -14

Storey, C, Hull, F. 2010. Service development success: A contingent approach by knowledge strategy. Journal of Service Management 21(2): 140-161.

Storey, C, Cankurtaran, P, Papastathopoulou, P. 2016. Success factors for service innovation: A meta-analysis. Journal of Product Innovation Management 33(5): 527-548.

Tseng, M.L.; Wu, K.J.; Chiu, A.S.F.; Lim, M.K.; Tan, K. 2018, Service innovation in sustainable product service systems: Improving performance under linguistic preferences. International Journal Production Economic. 203, 414-425.

Urde, M., Baumgarth, C., \& Merrilees, B. 2013. Brand orientation and market orientation-From alternatives to synergy. Journal of Business Research, 66(1), 13-20.

Van de Vrande, V, De Jong, J, Vanhaverbeke, W. 2009. Open innovation in SMEs: Trends, motives and management challenges. Technovation 29(6-7): 423-437.

Visnjic, I, Wiengarten, F, Neely, A. 2016. Only the brave: Product innovation, 
service business model innovation, and their impact on performance. Journal of Product Innovation Management 33(1): 36-52.

YuSheng, K. and Ibrahim, M. 2019. Service innovation, service delivery and customer satisfaction and loyalty in the banking sector. International Journal of Bank Marketing. 12, 1- 20

Zhang, J., Jiang, Y., Shabbir, R., \& Zhu, M. 2016. How brand orientation impacts , $1-33$.
B2B service brand equity? An empirical study among Chinese firms. Journal of Business \& Industrial Marketing, 31(1), 83-98.

Zhang, J. X.; Xie, H.Y.; Li, H.; Timothy, R.; Pu, S.; Deng, Q.X.; Jin, W.X. 2018. Integrated Framework of Growth Management for Identification of Service Innovation Levels and Priorities. Sustainability 10 